\title{
Techniques of World-Making in Medieval Armenia
}

In the last chapter I explored the Silk Road and Armenia as stories told, in the Middle Ages and in modern imaginations. Now I will "zoom in" on Armenia, one of the worlds that made up the wider universe of the Silk Road cultural ecumene. As I discussed in the introduction, I do not want to say that the medieval world was just a scaled-up version of daily life in Armenia, or conversely that daily life in the medieval South Caucasus was a scaled-down iteration of broad cultural phenomena happening "everywhere at once." Both of these presume a sameness about the global medieval that I want to turn over and look beneath, in order not just to understand the large-scale cultures of what we now call the Silk Road, but also to understand how people living in relatively remote places related to their world through practices which reached across scales. Plural scales of distance and difference and their embodied, emplaced experience are important for the imagination of worlds and thus for cosmopolitanisms, for either medieval or modern people. So, I will look at the ways whereby the world was "told" in Armenia as a bundle of threads tangled up in the broader shared imaginary of Silk Road culture that many of us still live within.

\section{IMAGINING MEDIEVAL ARMENIA: HISTORICAL AND ARCHAEOLOGICAL CONSTRUCTIONS \\ OF A SPACETIME}

If the Silk Road is a place first imagined in literary narratives, then, through the work of historians and archaeologists, medieval Armenia has likewise been created. I used the lens of travelers' accounts in the last chapter to show how Armenia appeared as a place inhabited by certain kinds of people-or as a landscape of uninhabited, stony ruins. In this chapter I will continue that thread and look in 
particular at the textual and material ways that high medieval Armenia has been made and imagined, both in the recent past and in the medieval period. ${ }^{1}$ This discussion draws from a combination of texts, including medieval manuscript texts as well as epigraphic texts or inscriptions, and from data produced by archaeological excavations over the last century and a half.

The explicit imagination of high medieval Armenia by historians began in the medieval period of course. This period in Armenia begins just after the contraction of the Seljuk sultanate out of the highlands, and hinges in many ways on the Mongol invasions of the 1230 s and the subsequent Ilkhanid period, when Armenia was a province of the Mongol Ilkhanate centered in Tabriz. During this period the Armenian highlands were ruled by a class of princes known in historical documents as mec išxan, tanuter, paronac'paron-that is, as princes, lords, and "lords among lords." 2 Though deliberately self-referenced with a similar nomenclature, the princes of the high medieval period were not of the same landed naxarar dynasties that had been favored by the Sasanian Persians, crowned by caliphs and emperors, and dispersed before the Byzantine and Seljuk armies. ${ }^{3}$ According to Robert Bedrosian, this emergent princely echelon was comprised of, on the one hand, "men of ambition and military talents" who were rewarded with titles and lands by the victorious Zak'arids for their service; and on the other, by the so-called mecatun class: merchants who had prospered from expanding highway trade and who accumulated assets and estates through purchase, often in cash. ${ }^{4}$ Ongoing research suggests that the Seljuk impact on the structure of the naxararut'yun had more to do with the redistributive effects of the iqta patronage system on estates already consolidated under the Bagratids than with a violent, physical dispersal of the aristocracy. ${ }^{5}$ Regardless, in the post-Seljuk period a number of new princely lineages were founded "by sword or by gold," and by the thirteenth century there were one hundred such families recorded, including the Vačcutyans, Orbelyans, and the neophyte houses of Tigran Honenc', Umek, and Samadin. ${ }^{6}$ One thing these new dynasties had in common with their early medieval antecedents was a strong interest in the writing of history, and of their own history in particular. Our knowledge of this period comes from the pens of historians who were supported by princely houses, or who were in fact members of those houses. A primary legacy of medieval Armenian society-beyond the spaces it built and the cultures it participated in-was an account of medieval events written by Kirakos Ganjakec'i, Step'anos Orbelyan, Vardan Arewelc'i, and numerous others. Unsurprisingly perhaps, the protagonists of these medieval sources were the same princes and princely actors under whose patronage the histories were written. Within these texts, the Caucasus landscape is frequently reduced to the backdrop of battles, treaties, patriotic miracles, and other princely exploits.

After residing in monastic scriptoria for several centuries, this medieval corpus (including historical texts from the previous centuries of the Middle Ages) was revived, transcribed, and printed for a mass readership in the eighteenth century 
-not in Armenia, but in centers of the renaissance of Armenian language and scholarship such as Venice and Vienna. There, members of the Mekhitarist order of Armenian Benedictine monks produced medieval imaginaries of naxarars and pastoral Christian kingdoms carrying on an ancient and autochthonous way of life. ${ }^{7}$ The Mekhitarist historical tradition is a classic example of what Benedict Anderson called "imagined community" or what Eric Hobsbawn and Terrence

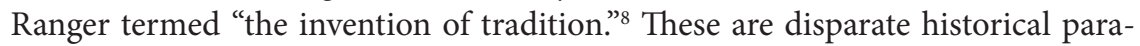
digms that call attention to the effervescent production of shared imaginaries of national and individual selfhood, in relation to (though not necessarily located within) a common homeland. Anderson made the critical point, relevant in the case of the Mekhitarists, that the modern imagination of national communities takes place across borders and at global scales, mediated by circulating print cultures. As Razmik Panossian has argued, "aware of and in conjunction with the intellectual currents of European thought, [the Mekhitarist writers] were very consciously and systematically carrying out an enlightenment project on behalf of the nation." They achieved this project, printing and distributing primary historical sources and synthetic histories of Armenia and her peoples from presses on the island of San Lazzaro in Venice.

The work of the Mekhitarists as historiographers was as significant or more so than their achieved revival of Armenian language. In both new and widely distributed reprints of the original texts, as well as in authoritative synthetic works, ${ }^{10}$ they produced medieval Armenia as a landscape that readers could imagine. Their version of Armenia was particular and nationalistic: proud mountain dynasties, ancient traditional Christianity, remote monastic centers, and heroes taken from the dynastic histories. This imagined medieval world is rooted in the built world of medieval monuments that survived in the nineteenth century, and which sparked the imagination of historians like Łevond Ališan. A member of the Mekhitarist congregation in Venice in the first half of the nineteenth century, Ališan produced historical geographies of regions of Armenia including Ararat, Shirak, and Sisakan (Syunik). These geographies contain records of Urartian and Persian as well as Armenian inscriptions, and engravings of Armenian villagers living among medieval ruins in the mountainous landscapes of the South Caucasus.

This medieval landscape has played a central role in the imagined Armenia which has united diasporic communities, and in the political knitting-together of the modern Armenian nation-state. Medieval spaces are the location of major acts which produced the Armenian nation as it self-identifies, such as the state conversion to Christianity (memorialized on a seventh-century stela at Talin) or the fifth-century referenda against diophysite tenets of Chalcedonian Christianity at the city of Dvin. Increasingly important in the twentieth century as Armenian nationalism was oriented in relation to the Soviet Union, the medieval past presented a bucolic rural Armenia as an opposition view to Soviet modernism. ${ }^{11}$ Armenian tradition (like that of many of the minorities within the USSR) was 
discursively situated as the past to the future of Soviet state citizenship. Medieval churches and monastic sites-among them Gełard and Ejmiatsin-are a reference point for diaspora identity, influencing the shape both of Armenian churches and also of community centers in other countries. ${ }^{12}$ The medieval landscape has long been the dwelling place of Armenian national nostalgia for an idealized past, prior to the stresses of both genocidal dispersal and modern global marginalization. This is well illustrated by Sergei Parajanov's 1969 film Color of Pomegranates (Sayat Nova), one of the most famous and highly regarded expressionist films of the Soviet period. In portraying the life of eighteenth-century poet Sayat Nova through the lens of surrealism, the film provided variations on the theme of an eternal medieval Armenia, filmed in a series of ruined gavit (narthex) spaces and on the roofs of high medieval churches. ${ }^{13}$ Key scenes in the film were produced at the sites of Hałpat, Sanahin, Sałmosavank', and Ałtala, tenth- to- fourteenthcentury monasteries restored in the Soviet period. Parajanov combined Safavid and Qajar imagery (of Sayat Nova's own time) with medieval spaces, to create a sense of a timeless, attenuated, and medieval premodernity. The vision of medieval Armenia that dominates artistic narratives is often that of a place to go in the mind to escape modernity, with all of the complexity, interconnectivity, and change that modernity entails for many people. This wishful imaginary has in many ways discouraged the scholarly development of an image of a complicated medieval Armenia, even though-as I will explore in the next sections-life in medieval Armenia was dynamic and profoundly engaged with multiple worlds, be it the produced worlds of Armenian politics or the Silk Road world(s) beyond the mountain horizons.

\section{Nodes and Networks: The History of High Medieval Armenia as a History of Trade}

If popular imaginations of medieval Armenia focus on pastoral and monastic scenes, the gaze of historians and archaeologists has long been focused elsewhere, on the "trade cities" of the medieval highlands. In long-standing historical conceptualizations of the medieval period the later centuries of the Middle Ages are important because it is at that point that somehow the conditions are established for various forms of emergent modernity. In mid-twentieth-century models of economic and political history written in both the West and the Soviet Union, this meant that agrarian societies needed to form urban centers, places where people would be crowded together, and where identities like artisans, craft specialists, and a middle class could form. ${ }^{14}$ Furthermore, the social mobility in medieval cities enabled medieval people (according to these same models) to break free from "local" ties to land, and to become worldly, enlightened cosmopolitans. If towns were considered important as central concentrations of complex social life, they were also understood as nodes in networks of movement and exchange. Histories of high medieval trade frequently emphasize cities and towns, ${ }^{15}$ in stark 
contrast to the desert dunes and romantic, isolated oases at the center of historical imaginaries of the Silk Road. Histories of the medieval social landscape of Armenia are caught up in the old idea that active trade and dynamic urban life depend on each other-and that cosmopolitanism is a capacity exclusively of cities. For our purposes, these models are important because they are the "story" about the Middle Ages that was used to tell other stories in places like Armenia, and which guided the questions asked of archaeological and historical records. They also provide the cast of potential protagonists of those stories: cosmopolite urban mercantile elites, making their fortunes from the wide world rather than the narrow breadth of a plowed furrow and the tight cycle of the seasons. To rephrase an old German phrase loved by historians of the medieval economy, "city air makes us cosmopolitan."

The fundamental historical source for discussions of the Armenian highlands' role in regional trade, and the relationship between trade movement and urbanism, is Hakob Manandyan's Trade and Cities of Armenia in Relation to Ancient World Trade.${ }^{16}$ Manandyan traces the rise and fall of urban places in the highlands based on the mention of cities in medieval texts, and from this narrates the ebb and flow of trade which nourished, and was supported by, those cities-though he does not use the term Silk Road. Reconstructing itineraries from late classical and Arab sources, Manandyan tethers the highlands into connections of movement and trade with the worlds to either side. For the period between the late twelfth and fourteenth centuries, this means drawing maps of networks in flux. Manandyan draws special attention to the crystalization of routes and markets made possible by the Venetian and Genoese colonies on the Black Sea coast, in particular the Venetian port at Trebizond. According to Manandyan, these waystations for the European quest for eastern goods galvanized travel, and in turn trade cities, on the routes through the Caucasus. ${ }^{17}$

For Manandyan, the Mongol invasions of the mid-thirteenth century present a quandary of evidence: on the one hand, historical sources attest to the destruction of cities and general depopulation; on the other, he argues that the shrewdness of the Armenian nobility spared the highlands from the destruction meted out elsewhere, such that social life was restored in Armenia by the latter part of the century. Manandyan argues that trade was not only restored but in fact flourished, supported by Mongol grants of safe passage for caravans and attested in epigraphy. ${ }^{18}$ Manandyan draws on the description written by the Florentine agent Balducci Pegolotti of the transit fees required for transporting merchandise overland from Ayas to Tabriz under the Ilkhanids. Writing in the fourteenth century, Pegolotti had divided the total fees into categories, which are also categories of place: the taxes paid by load ("whether of camels or of other beasts") at the entrances to cities, upon leaving cities, and at bridges and caravanserais. ${ }^{19}$ The landscape of Manandyan's imaginary medieval highlands draws on the landscape as evoked in such itineraries, a network of cities strung like beads on a string made 
of infrastructure, tautened at either end in accordance with the desires of distant urbanites in Venice and Guangzhou. ${ }^{20}$

The narrative of Armenia's role in a wider medieval world is elaborated by Babken Arak'elyan, who served as the director of the Institute of Archaeology and Ethnography from 1959 to 1990. In his two-volume synthesis of historical and archaeological evidence, Arak'elyan argues that the ninth to the thirteenth centuries witnessed the transformation of Armenia's feudal society through the development of a division of labor in urban artisanal production, and a proliferation of trade organizations centered in the highland cities. ${ }^{21}$ Arak'elyan cites the chronicles of medieval historians, who remarked on trade in the cities of Dvin, Ani, Xlat, and Kars, as well as Nprkert, Arzn, and Bałeš; he also extrapolates from the midcentury excavations at Garni to argue for the widespread development of commodity production and market activity in towns. ${ }^{22}$

According to Arak'elyan, despite the nugatory effects of the Seljuk invasion and rule of the Caucasus, "in the second half of the twelfth century, and lasting until the Mongol invasions, the cities experienced a rise, and as in the rest of the Near East, in Transcaucasia craft production and trade reached its medieval apex." ${ }^{23}$ This corresponds to what archaeologists and historians after Arak'elyan have referred to as the later "developed" (zargacac) medieval period (late twelfth through mid-fourteenth century); a phase of rapid transformation, as the division of labor and class differentiation in cities pulled the highlands towards capitalist modernity. ${ }^{24} \mathrm{~A}$ phrase that Arak'elyan used constantly through his analysis was "the uncoupling of the cities from village agrarian subsistence," casting Weberian emphasis on the funneling of human labor and creativity out of the static relationships of subsistence agriculture into the dynamic proto-capitalism of merchant cities. Drawing on the work of the Russian historian Yakubovski, Arak'elyan even went further to assert that social life in Near Eastern cities (among which those of Armenia are numbered) surpassed Europe in its "richness and culture." 25 This process only deepened in the latter centuries of the high Middle Ages. Arak'elyan argued that over the course of the late twelfth to early thirteenth centuries trade and craft production expanded despite the slowing effects of Seljuk rule, accompanied by a greater contrast between city and village, and a deepening of class differences within the urban population-including the emergence of an elite upper class. ${ }^{26}$

But I want to draw attention to another argument of Arak'elyan, which has been overlooked in the emphasis on transit trade and the "rise" of cities. Critically, Arak'elyan switched the emphasis from external, transit trade to internal trade as a prime mover for the economy of tenth- through thirteenth-century Armenia. Arak'elyan drew on the epigraphic evidence from the city of Ani to argue for a rising importance of urban shops and markets in this period, as a source of social as well as actual capital. ${ }^{27}$ Though carried out, as he argued, in urban markets, this trade economy followed seasonal cycles, and was punctuated by festivals. ${ }^{28}$ Likewise, through an examination of the implications for the geography 
of trade of the laws contained in Mxitar Gošs Lawcode, Arak'elyan argued that trade in the twelfth through thirteenth centuries took place "not just in cities, but in settlements as well, and in the provinces trade may have been contained within particular places, such as the nodal points of roads, in convenient places and during festival markets." 29 Likewise, this regional trade "embraced as well the products of agriculture and pastoralism and their processed materials (wine, oil, wax etc.) and raw materials (leather, cotton, silk, vegetable fibers etc)." ${ }^{30}$ It is important that Arak'elyan drew attention to regional economies in Armenia, and in particular, to the landscapes and cyclical, ritual practices within which such economies were rooted. Arak'elyan's point confirms and encourages my own impulse to look, not just at world-cities, but also at local landscapes for the construction and support of trade cultures and of cosmopolitanism.

Soviet historians of the latter twentieth century referred to the twelfth and thirteenth centuries in the highlands as the "Zak'arid period," after the Armenian Zak'aryan noble house which led the Georgian Bagratid armies in driving out the Seljuks from the highlands, and who ruled much of central and northern Armenia in the name of the Georgian crown. ${ }^{31}$ Within the arc of high medieval transformations, the Zak'arid period is presented by historians as a window of progressthough a brief one. According to Arak'elyan, the Armenian cities experienced a rebirth once freed from the "yoke" of Seljuk rule. ${ }^{32}$ Barely a generation separated the end of the Seljuk era and the Mongol invasions of the Caucasus; as we saw in the last chapter, these changes occurred within the living memory of people like Šahnšah (Rubruck's Sahensa) Zak'aryan. The Zak'aryans were praised by the thirteenth-century chronicler Kirakos Ganjakec'i, in terms that demonstrate that the impact of these administrators and their Georgian rulers manifested in concrete ways in the architecture and landscape of this period: "They restored many monasteries which for a long time-since the invasions of the Ishmaeliteshad been in ruins. They restored the churches once again and the clerical orders shone forth. They also built new churches and monasteries, which from antiquity had not been monasteries." 33 This excerpt from Ganjakec'i demonstrates for the medieval period a fact that geographers have repeatedly asserted for modern globality: that trade dynamisms and integrated economies depend on built space. ${ }^{34}$ Manandyan argues that the evidence for monumental and urban construction under the Zak'arids was further evidence for the role played by mercantile elites in international trade. ${ }^{35}$ Arak'elyan stresses the necessary links between expanding medieval trade economy and built infrastructure: "the developments of trade depended on the improvement of trade highways, on the construction of bridges and caravanserais on the highways and in mountain passes, and on the creation of pandok-ijevanatnner (inns), shops, hostelries, and other facilities in the cities." ${ }^{36}$ Such assertions push against the nodal understanding of trade and cosmopolitanism as moving fluidly between cities; the resulting broad geography of trade infrastructure and culture also raises questions for a medieval archaeology decentered from urban sites. Arak'elyan's assertion also centers the importance of 
cultures of construction, endowment, and maintenance-what he called an "issue of care in Armenia" ${ }^{37}$ - for the creation and perpetuation of a cosmopolitan world linked through the highlands.

\section{Modern Encounters with Medieval Landscapes}

The narratives devised by Armenian historians for the high Middle Ages were coconstructed with the study of standing ruins and excavated physical landscapes of that period. Active interest in the physical remains of the medieval past began, of course, in the Middle Ages. As I will discuss in the following chapters, we know that people in the high Middle Ages both actively reconstructed ruined buildings, such as churches, and recorded partially effaced inscriptions. As mentioned earlier, interest in this ruined past was revived by antiquarians and travelers in the nineteenth century. Compiling histories of the Armenian provinces, Łevond Ališan and his contemporary Yovhannes Šahxatunyan created records which remain some of the only descriptions of buildings and inscriptions which were extant in the nineteenth century and have since collapsed or been destroyed. ${ }^{38}$ Multiple European travelers in the early modern period remarked on medieval sites in Armenia. Jean Chardin, en route to Isfahan in 1672, visited Ejmiatsin and the neighboring monasteries of Sb. Hripsime and Sb. Gayane. ${ }^{39}$ By the nineteenth century, a major attraction for antiquarian travelers was the ruined medieval city of Ani. Located on the Akhurean River west of Mount Aragats, Ani was the capital of the Bagratid kingdom in the tenth century and was a bustling city until the fourteenth century. Due to shifts in trade routes, a series of seismic disasters, and the vicissitudes of geopolitics, the core of Ani was empty by the beginning of the nineteenth century. In 1817, Robert Ker Porter passed by the ruins of "Anni" and fitted them into a larger reflection (which dominates his travel account) on the decline of great eastern civilizations and the rise of the West:

On entering the city, I found the whole surface of the ground covered with hewn stones, broken capitals, columns, shattered, but highly ornamented friezes, and other remains of ancient magnificence. Several churches, still existing in different parts of the place retain something more than ruins of their former dignity; but they are as solitary as all the other structures, on which time and devastation have left more heavy strokes....

... As I passed by [the ruined houses], and over the almost formless masses of yet more extensive ruins, I could not but think of the interesting stores of antiquity which might be lying hid beneath those mighty fragments of columns, walls, and heaps of stones. Even a few days gathering on the surface would furnish a traveler (could it be attempted with any degree of security) with very fine specimens of the most beautiful ornaments of architecture. ${ }^{40}$

As is clear from these brief excerpts, Ker Porter was typical of the "antiquarian moment" in the history of archaeology as a science, when archaeological sites (picturesque ruins) were useful primarily for the furnishing of romantic reflections 


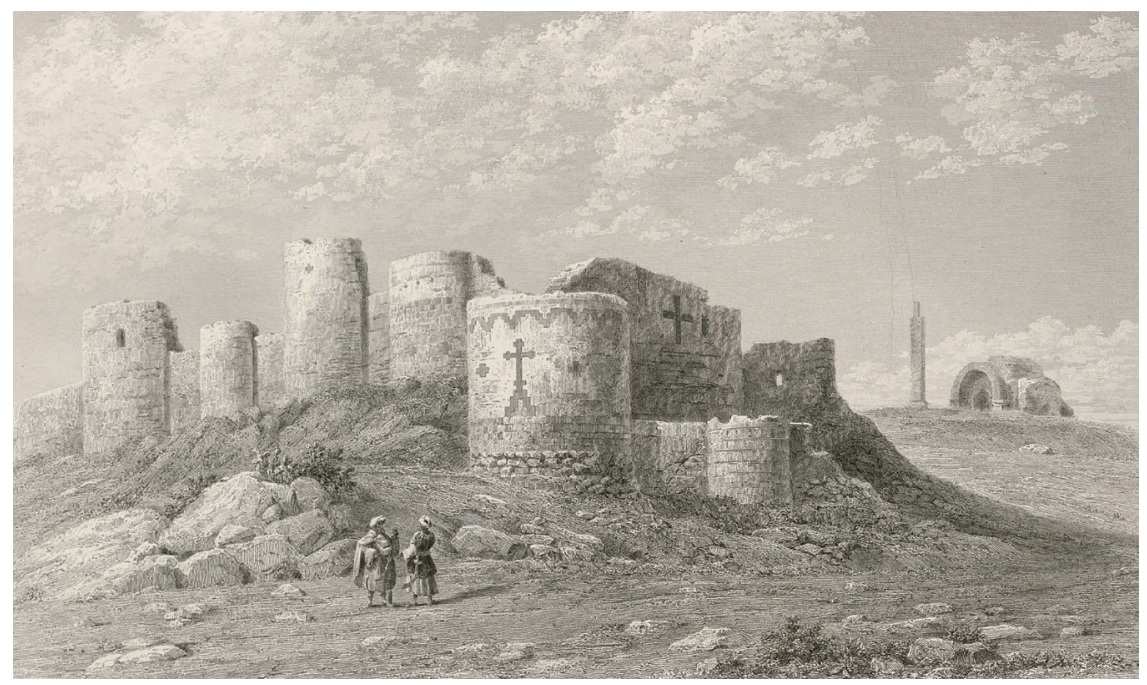

FIGURE 3. A Romantic nineteenth-century view of the walls of Ani, by Charles Texier, from his 1842 Description de la Armenia, la Perse, et la Mesopotamie. Note the figures in the foreground which both provide scale and a dynamic contrast between Christian past and Oriental present. Public Domain from archive.org.

and beautiful ornaments to the sentimental gentleman traveler. Nearly a century later, as archaeologists took advantage of the potential Ker Porter observed beneath his feet, the ruins at Ani furnished evidence for similar arguments for medieval Armenia’s relationship to medieval and modern worlds (see fig. 3).

The excavations undertaken at Ani by Nikolai Marr were the first such scientific excavations carried out in Armenia. ${ }^{41}$ The first director of the Russian Academy for the History of Material Culture, Marr has been described as "a linguist with archaeological interests," and was primarily invested in constituting a unilinear, singular, and transhistorical Armenian culture tied to the Armenian language. ${ }^{42}$ Marr initiated systematic excavations at prehistoric sites as well as at the great medieval cities of Armenia, Ani and Dvin. Marr's excavations at Ani in 1892, 1905, and 1907-13 exposed enormous areas of the site and produced a wealth of architectural data and material artifacts. Marr's landmark publication primarily focused on the historical context of the city of Ani, and left much of the task of analyzing this material corpus in the hands of his successors..$^{43}$ The first generation of Marr's students in Armenia, working after the First World War, expanded the remit of archaeology to include investigations at multiple urban centers as well as the fortified citadels and monasteries built by the medieval nobility. Critical during this period was the work of T'oros T'oramanyan, an architect who is best known for his reconstruction of Zvartnoc' Cathedral. T'oramanyan undertook and published regional surveys throughout Armenia, which left as a legacy a landscape-scale 
dataset of medieval churches, fortresses, caravanserais, cemeteries, and village sites from multiple historic periods (see chapter 4$).{ }^{44}$

As geopolitical realities forestalled research at Ani, archaeologists within the newly formed Armenian Soviet Socialist Republic turned their attention to major urban sites within the country, specifically the site of Dvin, the capital of Sasanian and Arab Armenia (fifth to tenth centuries) and a major urban center into the High Middle Ages. Marr had begun test digs at the site in the early part of the century; systematic excavations were resumed at Dvin in 1937 under the direction of historian Smbat Ter-Avetisyan and archaeologist Karo Ghafadaryan. Excavations at Dvin would continue nearly uninterrupted until the collapse of the USSR in 1991, to be reopened again in recent years by Ghafadaryan's students; excavations were directed from the 1970 s onward by Aram Kalantaryan, who worked at Dvin with a team of medieval archaeologists until the year of his death, in 2009. ${ }^{45}$ The synthetic publications, monographs, and dissertations generated from the Dvin excavations have supplied a broad and rich conceptualization of social life at that capital city during its span of medieval occupation, from the seventh through thirteenth centuries. The extensive and rigorous work done at Dvin over the last century provided the basis for comparative analysis and stratigraphic dating for contemporary sites from the high medieval period, including the medieval levels at Garni, the Bagratid fortress at Anberd, and the Zak'arid-era castles at Vardenut and Daštadem. ${ }^{46}$ The extensive corpus of artifacts from the citadel, lower town, and central quarter of Dvin also generated a body of data for ongoing, detailed research on the production, use, and circulation of late medieval material culture, including ceramics, glass, and metal work. ${ }^{47}$

\section{Life beyond the Cities}

For most of the twentieth century, the archaeological focus on Ani and Dvin shored up the historical model of high medieval society as being city-centered. In recent years, however, motivated in part by the need to rescue or rebuild sites across Armenia, excavations have been carried out at a greater diversity of sites. The majority of these sites are monasteries, many of which now consist of only a few standing church buildings, as their refectories, outbuildings, and adjoining settlements are built over by modern villages. In rural and mountainous parts of Armenia, this tendency to reduce extraurban medieval settlement to a church and a cemetery was exacerbated by agricultural amelioration in the Soviet period. Though recognizable church buildings might be assiduously avoided, outbuildings and entire ruined villages were bulldozed into canyons or collected into heaps of rubble to make room for industrial farm collectives and upland fields. ${ }^{48}$

Many of the monastic sites excavated were chosen because they had ties to historically significant princely houses, such as the Bagratunis, Orbelyans, or Vačutyans. Excavation at these sites thus served a dual purpose of augmenting the textual record by producing new inscriptions-and indeed, many of these 


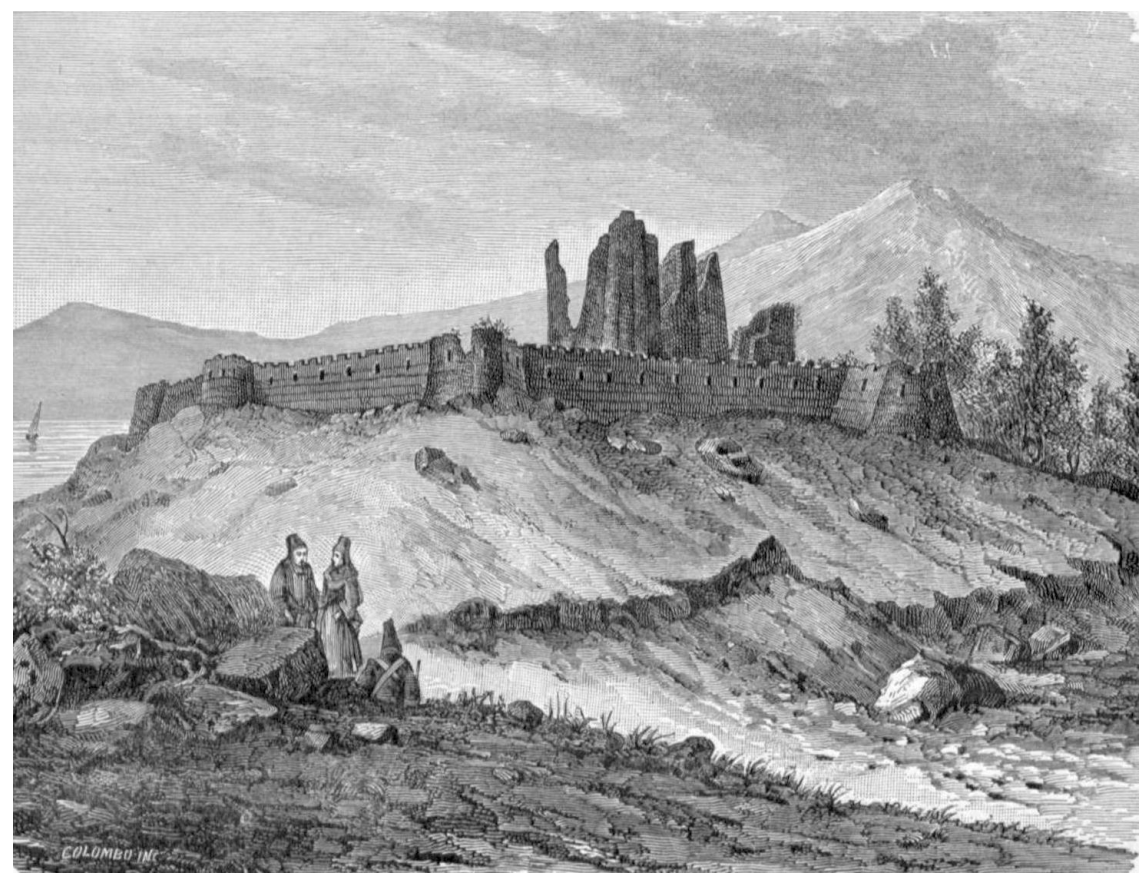

FIGURE 4. An engraving showing the fortress of Daštadem (Nor Talin), from Łevond Ališan's 1890 Ayrarat. Note the contemporary Armenians added for scale and romance, as well as the medieval and later fortifications. Public Domain, Bonn University Digital Armenian Archive.

excavations were led by historians rather than archaeologists. ${ }^{49}$ These include the twelfth-thirteenth century site of Tełenyac' Vank', located in the foothills of the Tsaghkunyats in the juncture of the Kasakh and Hrazdan River valleys, or the monastic site of Marmašen, nestled in the Akhurean canyon, north of Ani. ${ }^{50}$ In other cases, excavations were undertaken for rescue or reconstruction purposes; a prime example is the fifth-through seventeenth-century site of Uši Vank', located on the southeast shoulder of Mount Aragats. ${ }^{51}$ Extensive sections of this monastery dating to the developed medieval period were excavated in order to reconstruct a small chapel at the complex's center. ${ }^{52}$ These monastic excavations are complemented by recent work at fortified and monumental sites associated with the medieval elite, including excavations at the sites of Bjni, Tsałatskar, and Yełegis. ${ }^{53}$ For almost a decade, archaeologists from the Institute of Archaeology in collaboration with a series of international teams have excavated the fortress at Daštadem, located on the southwestern shoulder of Mount Aragats, south of the city of Talin (see fig. 4). These excavations have uncovered fortifications dating to the Sheddadid, Zak'arid, and Safavid periods, and have also provided extensive material data on daily life in a highway town in the twelfth to fourteenth centuries. ${ }^{54}$ 


\title{
Shifting Perceptions of the Landscape of High Medieval Armenia
}

For more than a century, excavations into Armenia's medieval past have generated a material narrative which has been interpreted through, but which also sometimes challenges, the models constructed by historians. Of primary interest to me, and to this book's project, is the reconfiguring view of the Armenian social landscape that is emerging from accumulated archaeological evidence, and from changing archaeological questions. This is happening due to a number of factors, many of which have to do with the reconfiguring sources of institutional support for archaeology and increased international collaboration. But also, our imagination of the medieval Armenian landscape is reconfiguring as medieval archaeology more generally moves from what were long thought to be the centers of medieval life - the castle, the church, and the city — and engages with a broader social landscape. ${ }^{55}$ It is also, slowly, reconfiguring away from a traditional focus on the lives and doings of a small number of royal figures. Patricia Blessing and Rachel Goshgarian, writing on the social production of space in medieval (twelfth to sixteenth centuries) Anatolia, phrase this shift nicely: instead of asking "who was in power," the collective focus of their study is "where, in what places, was power?" in this period ${ }^{56}$ Medieval archaeology in Armenia is therefore following a trend already established elsewhere,$^{57}$ though one which has not fully transformed the narratives of medieval social complexity everywhere.

This expanding landscape of excavation and research is the context for my own projects in Armenia. Moving from an urban-centered to a landscape-scale imaginary of medieval sociality in Armenia is crucial for rethinking that world, and what it meant to people living in it. Put another way, if we expand our imagination of medieval Armenia to include small towns, village houses, and roadside places, then those too become locales for the situating of cosmopolitan subjects, people who imagined the Silk Road into being. To begin, I will examine how this landscape-of cities, towns, and churches, but also fields, villages, roads, bridges, and inns-was imagined by political actors in the thirteenth through fifteenth centuries. By looking at how places were tied to one another through the practice of inscription (engraving in stones), we can get a sense of how the world was linked together for and by medieval people both living in Armenia and passing through it. This step in my multiscalar archaeology of Armenia's place in the Silk Road world is important, especially for helping to show that that world was situated not just in skeins of connected, nodal cities, but also in landscapes integrated and meshed with other mobilities, concerns, and rhythms of life.

\author{
MAKING WORLDS FOR OTHERS TO LIVE IN: \\ EPIGRAPHIC AND ARCHITECTURAL SPACETIME \\ IN MEDIEVAL ARMENIA
}

In medieval Armenia, shaping the landscape-whether in written representation or physical fabrics-was understood as a practice that was inherently political, 
and inherent to politics. According to the late twelfth-century Lawcode of Mxitar Goš, constructing monumental buildings was a right reserved for princes, and part of the princely obligation to maintain societal infrastructure. As he wrote: "If a king builds a city or a keep, if he keeps a census, and if he stamps or mints dahekans or drams, let him have authority according to the legal code. But it is not legal for princes to mint dahekans or drams; if he should mint them, it should be with the permission of the king. Likewise in building cities and castles. To build bridges over great rivers is the prerogative of kings; and as for hostelries and inns (pandok, ijawanac'tun), for these let it be with their permission." ${ }^{2}$ In the context of the mechanics of power in medieval Armenia, the "prerogative of kings" here demonstrates that the construction of a bridge or caravan inn was cause to cite the power and grace of the king to whom a prince owed their fealty, just as in the case of monastic donations. ${ }^{59}$ It makes functional sense for several reasons that to build castles, bridges, or caravanserai would be a right set aside for princely rulers. On the one hand, building these sorts of monumental public structures was expensive, and required the kind of resources that only the very wealthy could command. In another sense, however, Gošs stipulation about the princely right to build touches on the power invested in making spaces. Structures like churches, palaces, and caravan inns were (and are) spaces imbued with cosmological connotations; they were small worlds that situated and shaped the worldviews of people who moved within and around them. ${ }^{60}$ To have one's name attached to such a building was therefore to stake a claim as a builder of worlds. This link between power and infrastructure was not particular to medieval Armenia; rather, it was part of the shared culture which made travel, trade, and encounter possible in the medieval Eurasian world. The excerpt from Goš cited above is strikingly familiar to a piece of political advice given a century earlier, by Nizam al-Mulk, then vizier to the Seljuk Sultan Malik Shah I: "Further he will bring to pass that which concerns the advance of civilization, such as constructing underground channels, digging main canals, building bridges across great waters, rehabilitating villages and farms, raising fortifications, building new towns, and erecting lofty buildings and magnificent dwellings; he will have inns built on the highways and schools for those who seek knowledge; for which things he will be renowned forever." ${ }^{61}$ The similarity between these two philosophies of power suggests two things: first, that the practice of hospitality In Armenia was always-already cosmopolitan, participant within a rich world of Central Asian, Persian, and classical ideas. Second, these texts also reiterate the perceived unity between princely or royal power in or over a world, and the built spaces-including infrastructural landscapes-which were evoked as smaller worlds constructed in the name of that power.

Inscriptions, or texts carved into the stones of public buildings, served a parallel function. In addition to conveying literal information about what date churches were built and through whose donations, architectural inscriptions rooted themselves in the built landscape, constituting a distributed topography of mutually implicated structures, spaces, and texts that shaped the movement and 
imaginations of medieval people in Armenia and the broader Silk Road world. Within the more intimate space of the building itself, inscriptions could function as mnemonics for ritual and devotional acts in similar ways to imagery, enabling the iterative production of communities of practice. ${ }^{62}$ For the rest of this chapter, I explore how the nested practices of inscription (engraving text into stone) and circumscription (the interpellation of landscapes and everyday lives within such engraved textual projects) were ways by which Armenian men and women with aspirations to princely power built political worlds for themselves and their subjects. Central to this exploration is thinking about the ways that inscribed spaces produce subjectivity, or how the cosmological properties of architecture shape "people" as always-already "publics." The aim in these discussions is to frame architectural spacetimes built in medieval places like Armenia as microcosms of the world spanned by medieval Silk Road culture, and to inquire how they mediated the scalar transforms between embodied princely selves and plural worlds of medieval dwelling.

The medieval Armenian placement of donation inscriptions on the walls of churches was a practice rooted in long tradition, whereby the beneficence of the princely donor ensured a reiterative practice in that space by the katotikos (patriarch), monks, and congregants; these repeated Masses and prayers were engendered by the reading of the inscription, and guaranteed the salvation of the donor's soul. Mxitar Gošs prescriptive argument within the law code, that kings and princes must build monasteries "not for the sake of any corporeal hope but rather for a spiritual one," speaks to the clerical awareness that such endowments were a significant source of worldly influence as embodiments of princely piety. ${ }^{63}$ The practices undertaken by the medieval princes who were Gošs audience and patrons had long roots in highland tradition. Based on a collected corpus of Armenian inscriptions from the early medieval period (fifth through eighth centuries), Timothy Greenwood has demonstrated the coherence of the lexicon of epigraphic performances of power in the highlands. ${ }^{64}$ The builders of churches and donators of outbuildings, bell towers, libraries, and martyria were concerned with defining themselves both in terms of worldly networks-that is, in relation to kin, kings, and bishops-as well as assuring their place within a vertical order of Christian piety. The inscriptions displayed the donor's concern that their gifts ensure the salvation of their soul, to be remembered in prayer by the worshippers who congregated and circulated in the spaces they had constructed, endowed, decorated, or renovated.

Building on Greenwood's analysis, Christina Maranci argues that the inscribed exteriors of churches and other buildings in the medieval Armenian highlands were not meant to be merely tacit markers of ownership or attribution, but were intended to be read and reread in repeated rituals that involved movement and the evocation of shared ecumenical landscapes. ${ }^{65}$ This observation lends itself to the frequent medieval inscriptions which encircle churches in bands of writing, 
intended perhaps to be read during a liturgical circumambulation of the building, and also suggesting links to a broader medieval culture of decorating buildings, as well as human and nonhuman bodies, with bands of apotropaic text. ${ }^{66}$ Medieval Armenian inscriptions thus indicate a community of practice, for which the concept of inscribing social power through the reading of carved stone and the movement of bodies through space was epistemologically not only sensible but sensuously pious. That is, the practice of reading political cosmography from inscribed and endowed places was part of embodied practice for medieval Armenian people in places like the Kasakh Valley, who conceived of themselves as situated within legible worlds of holy and human power which were nested reflections of one another. ${ }^{67}$ The way these practitioners understood them, churches were machines built from words, stone, moving bodies, voices, scents, and objects, which worked to perpetuate the form of the social and spiritual cosmos.

I have discussed at length the idea of the Silk Road as a spacetime that has been written into being as much as lived, encountered, or constructed. At the local scale, Armenians in the Middle Ages also produced inscribed landscapes, both in historical texts and in a complex material-literary mode of writing about place in places. The inscribed landscape we can reconstruct from distributed, overlapping, and differentially legible inscriptions is a story told by medieval Armenians about themselves in stones and in the spaces between them. These are not the same as the stories contained in documentary histories (which have their own material and spatial properties). Think about the texts located in mountain valleys, above busy market squares, above the plastered halls of churches that bloomed with incense smoke and glowed with candles, ringing with the sounds of Mass. Other inscriptions were traced by the fingers of travelers as they passed through the low doors of caravanserais, having paid their fee to get out of the snow or heat and into a shelter for themselves and their pack animals.

The architectural inscriptions of princes in post-Seljuk Armenia demonstrate the efforts of people to situate themselves as political actors within worlds of their own making-and worlds which included not only the intimate details of everyday life in the valleys of Aragatsotn, Shirak, Ararat, Lori, and Vayots Dzor, but also a world of influence, taste, and power that stretched as far as quasimythical places like Venice or the Mongol court. These worlds of power contained not only the usual suspects of medieval history-priests, kings, and princes-but also a whole cast of characters, spaces, and material things, all of which were assembled together and circumscribed as a world on the wall of a building. The quintessential, and most studied, Armenian example of this practice of epigraphic world making is the case of the merchant prince Tigran Honenc', who endowed buildings and left his mark in inscriptions around the medieval capital of Ani. Tigran Honenc' is exemplary of the mecatun išxanner, the group of princes (or men and women who aspired to princeliness) in the thirteenth through fifteenth centuries who staked the claim of their political power in worlds that they set in 
motion, and commemorated in text and stone. ${ }^{68}$ Nikolai Marr, who uncovered many of the prince's inscriptions on fallen blocks and walls at Ani, called Honenc one of the most brilliant representatives of his medieval world of trade. ${ }^{69}$ In the year 1215, Honenc' dedicated the church and monastery of St. Gregory the Illuminator (Sourb Grigor Lusavorich), overlooking the Akhurean River. The entire south wall of the church is covered with an inscription framed by blind arcades, and carved flowers and birds. As you read the inscription, translated here, notice the variety of human and nonhuman agents drawn into Honenc's inscribed world:

In the year 664 (1215) by the grace and mercy of God, ${ }^{70}$ at the time of the rule in the city of Ani of the amir-spasalar and mandaturtuxuces Zak'aria and his son Šahnšah, I Tigran, servant of God, son of Suleyma Smbatawrenc', of the family of Honenc', for the long life of my lords and their sons built the monastery of St. Gregory, which was formerly called "Mother of God of the Chapel," on a rocky spot with precipices and covered with thorns, bought by me from the owners with honestly acquired means to its hereditary owners and with great labor and cost I surrounded it with a rampart. I constructed this church in the name of saint Gregory the Illuminator and I decorated it with all kinds of ornament, with Signs of the Savior and with holy crosses of gold and silver and decorative images, ornamented with gold, silver, precious stones and pearls, as well as with gold and silver lamps and with relics of the saintly apostles, with a fragment of the divine and lord-receiving cross, and all kinds of precious vessels of gold and silver and various ornament. I built all sorts of apartments for the monks and princes and I placed there priests who offer the body and the blood of Christ such that the mass is offered without fail in order to prolong the life of my lord Šahnšah and of his son and for the forgiveness of my sins. And I have given in gift to the monastery of St. Gregory the hayrenik, ${ }^{71}$ which I have bought in cash paid to their owners and so thus assembled: half the village of Gawrohonik, 5 dangs of K'arhat, ${ }^{72}$ half of the village of Mšakunik, half of the village of Kałatk, the whole of the village of Šamaksov, the village of Xuzac-Mahmund in the land of Kars, two dangs of the village of Šund, fields and the pandok [inn or caravanserai] of Xačorik. Of properties in the city the baths and the public fountain, the local hotel with its shops and the vaulted-roof pandok, the barn behind the baths, the stables of Ter Sargis and the barn which I bought, the threshing floor and the income from two oil-pressing mills, the stables and barns of the monastery, the garden which is in front of the gates of the monastery and the slopes from the Glijor Gate until the river, as well as the riverbanks, the garden that I bought at the Dvin Gate, half of a milling from the mill, all of [the revenue from] a fish trap, and two days a week [the revenue from] another fish trap, from the Glijor mill two days a week [the revenue] from a fish trap, between Besk'enakap until the bridge I bought a half of the river; four dangs of the hostelry of Papenc' and the shop which is at its door, all of the houses on the Street of Hatec'ik, all of the fields bought at the gates to the city, a vinery in Yerevan and one in Ošakan, a garden in Koš and one in Aruč, in a place called Mazot, one garden in Mren, in Tsmak, that called "the field of the katołikos." All the goods which I have bought, as well as the many others which are in mortgage which I have not inscribed here, I have given them to the monastery and their owners may reclaim them, as I have written in another will, if they pay in gold to the monastery. ${ }^{73}$ 
The inscription juxtaposes scales in fascinating ways. As he enumerates the properties and objects that he has endowed to the monastery, either as gifts or as sources of income, Honenc' moves from the sacred (the vestments of priests, bodies of saints, and the body and blood of Christ offered as sacrament during Mass) to the apparently prosaic (fish traps, oil presses). Honenc"s "matters of care" include single objects which are themselves spatiotemporally complex, ${ }^{74}$ such as relics or fragments of holy bodies, and a piece of the true cross, which is directly indexical to the body and power of Christ, as well as to the place of crucifixion in the Holy Land. While inscriptions tend to be regarded as evental or temporally flat (the date of their commemoration), the temporality of this inscription is expansive and complex. The timespans with which Tigran Honenc' concerns himself, which he collects within the assemblage of his influence, include the daily routines of monastics as well as of farmers and shopkeepers, innkeepers, and hostlers. He bestows two days in the flow of a river through fishtraps, the growing seasons of vines, fruit, and other crops, and the everyday activities as well as the life-courses of villagers. ${ }^{75}$ Honenc donates not just from wealth, but from his care for cyclical times-of seasons, of masses, of festivals and daily prayers-as well as slices of transient time: nights spent by travelers in the pandok of Xačorik. These diverse timelines are bracketed by the lifespans of Honenc's Zak'aryan benefactors (Šahnšah and his son), as well as by the afterlife of Honenc"s own immortal soul, the beneficiary of prayers, Masses, and monastic commemoration. This example demonstrates that the practice of epigraphic donation overall complicates oppositions between the spacetimes of local and global, and between the cyclical everyday, the eternal, and the historical.

\section{Buildings/Bodies/Worlds}

Honenc's inscription works as a world in miniature: he seems to think of, to care for, everything necessary for the perpetual life of the monastery he endowed. But there is more going on here as well, tied up in medieval Armenian ideas about cosmology and architecture. Within medieval Armenian (and broader Anatolian) religious cosmologies, the nature of reality was symbolic, and nested. The human soul was believed to be eternal and yet contained within the body; likewise, the body was a cosmological monad, a microcosm or miniature version of an enclosed, finite, and perfect world. ${ }^{76}$ Buildings like churches were also thought to be microcosmic, oriented in the path of the sun so as to stand in for the world in miniature, and enclosing the congregants assembled inside as a symbolic representation of a complete ecumene. The microcosmic symbolism of bodies and buildings could thus slip between each other, such that the self is thought of as a house for the soul, and buildings as extensions of selves. In other words, the metaphorical concept of "my body is a temple" was more than a figure of speech in medieval Armenia. This is vividly illustrated in the deployment in Armenian (and broader Caucasian) architecture of a Byzantine technique of donor portraiture. ${ }^{77}$ On church walls 
across Armenia, from the late twelfth into the fourteenth centuries, donors were physically represented as carved stone miniatures, holding in their hands a miniature model of the church they had donated (and upon which they were depicted). These architectural mises-en-abyme enable a fascinating visual and corporal nesting of metaphorical scales, between the church model, the modeled self, and the church-which, by suggested analogy, the viewer is invited to imagine resting in the cosmologically scaled grasp of embodied princely piety and power.

This slippage between selves, bodies, and built spaces is especially relevant to the case of Tigran Honenc's church at Ani. Mattia Guidetti has pointed out the linkages between the decorative motifs on the exterior and interior of St. Gregory's church and the broader material world of early thirteenth-century eastern Anatolia and the Caucasus. In addition to ties between the relief decoration and styles found on ceramics in the same period, Guidetti observed that the interior of the church is decorated in motifs drawn from Persian textiles. ${ }^{78}$ In particular, I am drawn to the encircled senmurvs, winged creatures with canine heads, above the southern pastaphorion entrance. As has been explored by Hakobyan and Mikayelyan, such creatures were a popular motif in Sasanian and Islamic textiles, as well as being common in Armenian art, both illuminations of princely garments and architectural sculpture adorning the "fabric" of churches (see figs. 5 and 6). ${ }^{79}$

The art historian Eva Hoffman has demonstrated the mobile cultures which influenced medieval craftspeople, discussing the way that images and decorative motifs spread across portable things like ceramics, metal wares, and wooden objects, architectural decoration, and bodily adornments like textiles. ${ }^{80}$ Silk textiles were not only one of the most portable of medieval luxuries, they were also tied closely to royal or noble bodily identity. This medieval idea of a recognizable and desirable powerful body is part of the shared lexicon of ideas about the world, and of the action of humans within it, which tied together diverse communities and cultures within a Silk Road world. As Thomas Allsen has explored in detail, clothing and cloth were critical technologies in the making of powerful people, and of worlds of power within and overlapping with the Mongol sphere. ${ }^{81}$ The medieval Eurasian political economy of clothing - and in particular, of silken gowns and robes-was central in solidifying relationships between Mongols and their subjects; however, it was not as such invented by the Mongols. Lynn Jones has reviewed in detail the role played by textiles in fashioning common political worlds at the Caucasus frontier earlier in the medieval period, specifically in the constitution of Armenian Bagratuni authority. ${ }^{82}$ In particular, the ceremonial bestowing of robes wrought with gold (literal investiture) functioned to situate Armenian kings as vassals of the Abbasid caliphate. ${ }^{83}$ Jones notes that the crowning of Gagik Artsruni as a king of Armenia was accompanied by a gift of embroidered robes from al-Muqtadir, the caliph of Baghdad. It is thus no coincidence that Gagik is in turn represented wearing elaborate robes figured with roundels on the walls of his renowned reconstructed church at Aghtamar. ${ }^{84}$ In this depiction 


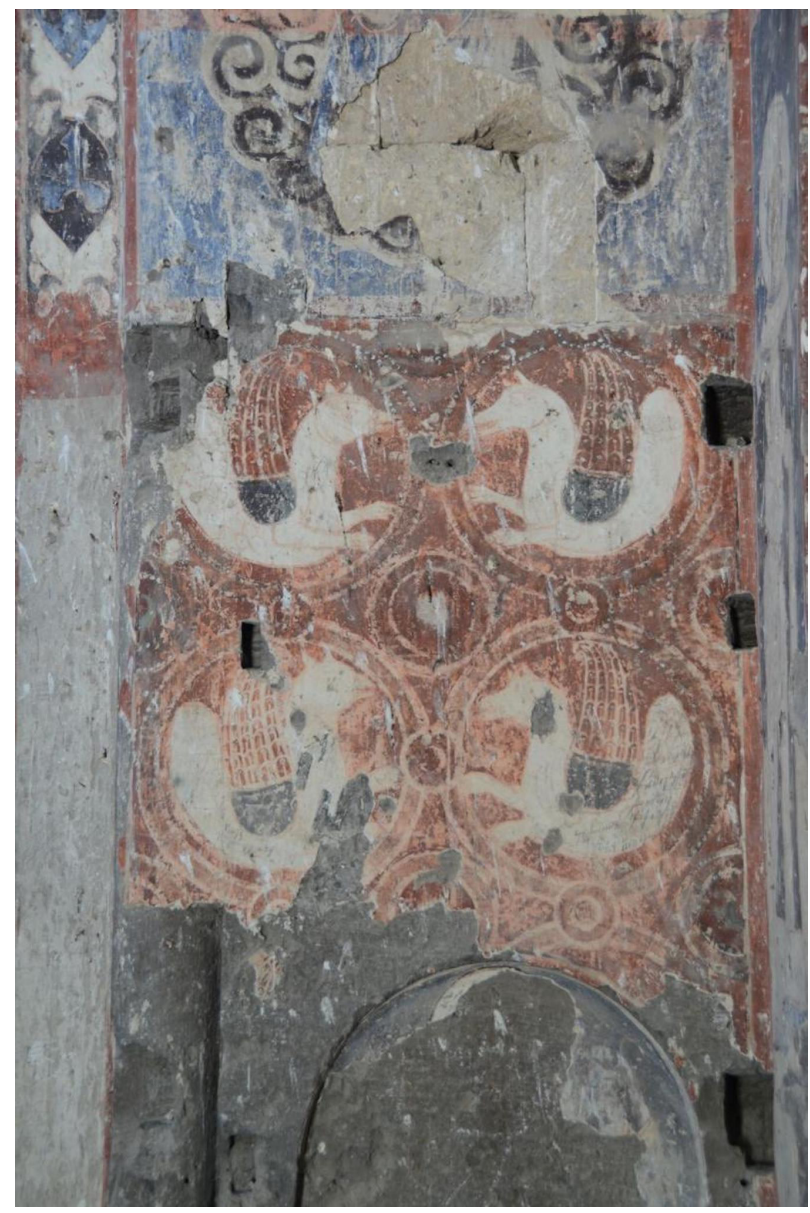

FIGURE 5. A panel of marvelous animal designs enclosed in crimson roundels above the entrance to the southern pastophorion of the church of St. Gregory at Ani. Photo credit: Ioanna Rapti, Crossing Frontiers Project at the Courtauld Institute of Art.

(one of multiple portraits), Gagik stands draped in silk, holding a model of the church; this portrait is part of a larger bas-relief decorative program which in turn clothes the church at Aghtamar in vegetal and figural designs. Jones further noted that the use of robes to transform a man into a king was adopted by the Bagratuni for their own ceremonies, thus constructing a local world of power in parallel; significantly, this second investiture took place within a church. ${ }^{85}$

Returning to the thirteenth century, the fact that Tigran Honenc's cathedral is "dressed" in the same way that he himself would have dressed (or aspired to be dressed) is an intimate allegorical link between the microcosmic space of the church and the spacetime of Honenc"s powerful body. ${ }^{86}$ These cosmological links between souls, bodies, and worlds are important when we look more closely at the process of epigraphic inscription and architecture as world-making. Epigraphic inscriptions demonstrate the ability of medieval actors to draw spaces, people, 
FIGURE 6. A Cilician Armenian medieval illumination from 1260 (Jerusalem MS 2660), showing King Levon and Queen Keran in silk robes with designs of lions and sirens.

Note especially the roundels and rampant lions on the king's robe. WikiCommons Open License.

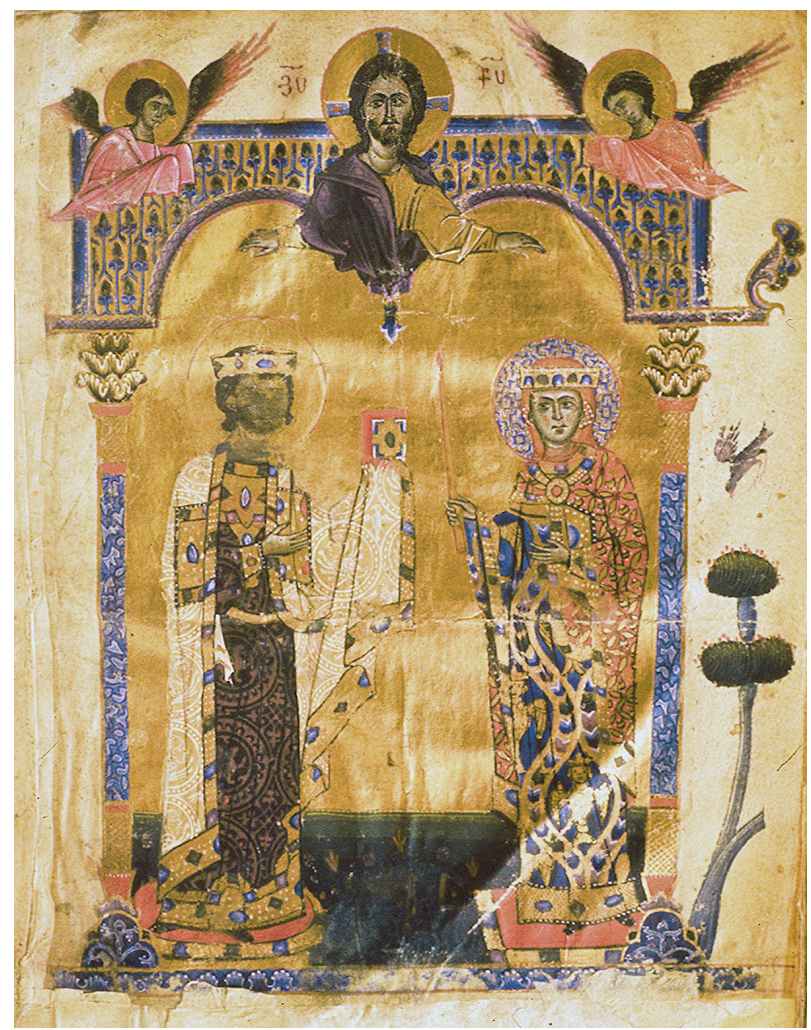

animals, objects, and landscapes into the spatial performance of their embodied efficacy. The version of a prince like Tigran Honenc' that we encounter on the wall of St. Gregory's (which we must read, our back to the rushing Akhurean, our neck craning to make out the words) is a sum total of the assemblage of things he had under his control. The fact that these things included the very prosaic (fish traps, stables), the exotic (wealth from long distance trade, the future embodied actions of priests) and the mystical (the body and blood of the Savior) is a testament to the encompassing nature of Honenc"s political world and the detailed, even loving attention of his princely care. Because this encompassing political world is assembled upon the building endowed (materialized or given body) by Honenc', the assemblage along with the building itself takes on a unity with the embodied self of the merchant prince. Tigran Honenc' is his endowment, is his assembled and donated world. The St. Gregory monastery of Tigran Honenc' at Ani is therefore a compound body, which is further compounded by the palimpsest of inscriptions layered upon it, that extend and permutate the embodied power of the original builder. A 1251 inscription on Tigran Honenc"s church was commissioned by a couple who described how "in the time of the Tatars" (after the Mongol inva- 
sion, under the Ilkhanid administration) they donated their familial storefront (kutpak), in the street of the shoemakers adjacent to the church. ${ }^{87}$ On the same church a similar inscription describes the bestowal of a stall in the street of the smiths (i darbno poloc in). As hopeful people continued to carve their gifts into the walls of Honenc's church, they appended their embodied selves, and the fabric of the city, to his corporeal power. Considered this way, politics in medieval Armenia is a strange but also fascinating cyborg of humans, animals, spaces, times, objects, labors, and words grafted onto each other through construction, endowment, and daily practice.

Over the course of this chapter, I have moved from the place of medieval Armenia as literarily and materially constructed by travelers, historians, and archaeologists, to the nested worlds constructed from words and stone (as well as assembled spaces, peoples, and things) by high medieval Armenian princes. One thing this span of discussion has suggested is the importance of scale for thinking about the question of how to make worlds, and how to live in them. This question in turn has implications for how we think about cosmopolitanism, the situation of self in relation to a world. Over the twentieth century, Armenia was written and materially reconstructed as a series of spacetimes with particular properties. It was evoked as a timeless land of national tradition, an engine of social transformation centered in medieval cities, a heroic landscape of princely exploits. By looking more closely at this last spacetime, I reflected on how princely power in medieval Armenian was intensely invested in the making of worlds for others to live in. Unlike the worlds reconstructed by Marxist historians, these inscribed, architectural worlds were complex and themselves multiscalar in time and space, framed by the span of a human body and spanning a whole cultural universe. This capacity of made worlds to collapse and expand, to enclose and reorient time and space will be further developed in the next chapter, situated in the Kasakh Valley. 